\title{
ANALISIS PEMBELAJARAN SISTEM AKUNTANSI MENGGUNAKAN DRAW.IO SEBAGAI PERANCANGAN DIAGRAM ALIR
}

\author{
Seprida Hanum Harahap \\ Universitas Muhammadiyah Sumatera Utara \\ Email :sepridahanum@umsu.ac.id
}

\begin{abstract}
ABSTRAK
Penelitian ini membahas tentang analisis pembelajaran sistem akuntansi untuk perancangan diagram alir dengan memanfaatkan aplikasi Draw.Io. Aplikasi ini memanfaatkan teknologi cloud maupun secara daring, dimana tidak perlu dilakukan instalasi pada komputer atau laptop dan juga telah tersedia untuk pengguna smartphone Android. Tujuan dari penelitian ini yaitu untuk menganalisis metode pembelajaran yang dilakukan untuk mata kuliah sistem akuntansi terutama pada bagian perancangan diagram alir. Simbol-simbol diagram alir diperkenalkan melalui buku teks, tetapi implementasi perancangannya belum efektif karena kendala waktu. Penggunaan aplikasi perancang diagram alir sebagai salah satu metode yang dapat diterapkan sekaligus mampu diserap mahasiswa pada saat kegiatan perkulahian.

Dari hasil penelitian ini digunakan untuk melihat tingkat kompetensi didalam menggunakan aplikasi dan daya serap mahasiswa terhadap diagram flow chart pada mata kuliah sistem akuntansi.
\end{abstract}

Kata kunci : Diagram alir, Draw.io, sistem akuntansi

\begin{abstract}
This research discuss the analysis of Accounting System to design flowchart with Draw.IO application. This application using cloud technology as well as online, there is no need to install on a computer or laptop and also available for Android smartphone users. The purpose of this research to analyze the learning methods that are carried out for accounting system courses, especially in flowchart design section. Flowchart symbols are introduced through textbooks, but the implementation of the design has not been effective due to time constrants.

The use of the flow chart designer's application as one of the methods that can be applied as well as able to be absorbed by students during the conciliation activities.From the results of this study are used to see the level of competence in using applications and student absorption to flow chart diagrams in the accounting system courses.
\end{abstract}

Keywords : Flowchart, Draw.IO, Accounting System.

\section{PENDAHULUAN}

Peranan teknologi informasi mempengaruhi kegiatan pembelajaran sehingga mampu meningkatkan kompetensi dan minat belajar bagi peserta didik dan mahasiswa. Flowchart atau diagram alir merupakan bagian yang paling penting didalam kegiatan perkuliahan sistem akuntansi dan sering digunakan untuk mengetahui prosedural dokumentasi dan pencatatan.Beberapa buku teks dan literasi mengulas tentang prosedur didalam sistem akuntansi dengan menggunakan flowchart. Praktik pengenalan diagram alir dilakukan dengan cara menggambar langsung pada media papan tulis. [1]Menurut Hanum (2017) bahwa perancangan dan desain flowchart memperkenalkan simbol-simbol flowchart tersebut melalui beberapa media yaitu 
dengan cara menggambarkannya di papan tulis, presentase dengan memanfaatkan proyektor dan referensi-referensi lainnya baik melalui buku-buku literatur, jurnal, sumber-sumber dari internet dan sebagainya. Pada awal pemanfaatan teknologi informasi, perancangan diagram alir menggunakan aplikasi perkantoran (office) seperti Pengolah kata, Lembar Sebar dan Presentase.Seiring dengan perkembangan teknologi informasi yang semakin pesat maka perancangan diagram alir semakin bervariatif. [2]Salah satu perusahaan vendor yaitu Microsoft merilis aplikasi yaitu Visio dengan kemampuan merancang diagram alir dengan ikon-ikon diagram alir yang lebih beragam. Tetapi pengguna yang menggunakan aplikasi ini harus membayar lisensi penggunaan aplikasi sebelum digunakan. Dengan kata lain yaitu penggunaan aplikasi Proprietary harus menggunakan aturanaturan penggunaannya diantaranya menggandakan, menyebarluaskan aplikasi. [3]Beberapa komunitas penggiat opensource telah mengembangkan aplikasi sejenis seperti Draw.IO, DIA dan sebagainya. Pada penelitian ini terfokus pada penggunaan Draw.Io dimana aplikasi ini tidak memerlukan instalasi apapun cukup dengan terhubung ke inernet dan membuka aplikasi internet browser. [4]Menurut Draw.io pada https://about.draw.io/about-us/ (diakses 2018) "draw.io is an open source technology stack for building diagramming applications, and the world's most widely used browser-based end-user diagramming application.". Didalam aplikasi ini tersedia berbagai jenis simbol-simbol dan diantaranya dibutuhkan dalam perancangan prosedur sistem akuntansi. Pemanfaatan aplikasi ini bersifat fleksibel dimana mahasiswa dapat menyimpan datanya dimana saja atau menggunakan media penyimpanannya sendiri. Untuk membuka aplikasi dapat dilakukan dimana saja dengan syarat harus terhubung ke internet.

Metode pembelajaran yang dilakukan dengan cara mempraktekkan langsung didalam perkuliahan tentang merancang flowchart dengan menggunakan aplikasi Draw.io dan dan kemudian memberikan penjelasan tentang prosedur yang terdapat di flowchart tersebut. Untuk itu maka penelitian ini mengagkat judul yaitu Analisis Pembelajaran Sistem Akuntansi Menggunakan Draw.Io Sebagai Perancangan Diagram Alir.

\section{METODOLOGI PENELITIAN}

Didalam penelitian ini dilakukan dengan cara penelitian deskriptif kualitatif yaitu mengungkapkan kejadian atau fakta, keadaan, fenomena, variabel dan keadaan yang terjadi saat penelitian berlangsung dengan menyuguhkan apa yang terjadi. [5]Menurut Satori (2011) mengungkapkan bahwa penelitian kualitatif dilakukan karena peneliti ingin mengeksplor fenomena-fenomena yangtidak dapat dikuantifikasikan yang bersifat deskriptif seperti proses suatulangkah kerja, formula suatu resep, pengertian-pengertian tentang suatukonsep yang beragam, karakteristik suatu barang dan jasa, gambargambar,gaya-gaya, tata cara suatu budaya, model fisik suatu artifak danlain sebagainya.

[6]Menurut Sugiono (2007), penelitian kualitatif merupakan metode penelitian yang berdasarkan pada filsafat postpositivisme, digunakan untuk meneliti pada kondisi objek alamiah, dimana peneliti adalah sebagai instrumen kecil, teknik pengumpulan data dengan triangulasi, analisis data bersifat induktif dan kualitatif dan hasil penelitian kualitatif lebih menekankan makna daripada generalisasi. 
Pada penelitian ini penulis mengungkapkan fenomena proses yang terjadi pada saat menerapkan aplikasi flowchart berbasis draw.io didalam kegiatan perkuliahan untuk mata kuliah sistem akuntansi.

\section{Hasil dan Pembahasan}

Berdasarkan hasil penelitian dalam mata kuliah sistem akuntansi ada satu subjek yang mempelajari tentang pengembangan sistem disuatu perusahaan. Untuk itu, ada beberapa media yang digunakan untuk perancangan sistem yang berkaitan dengan prosedur dalam hal ini yaitu flowchart. Pengembangan sistem melalui aplikasi diperkenalkan secara keseluruhan yang digunakan sebagai perancang flowchart diantaranya Microsoft Visio, Dia, Draw.Io, dan sebagainya. Masingmasing dari aplikasi ini mempunyai kelebihannya, seperti Microsoft Visio yang mempunyai tampilan antar muka yang intuitif dan fleksibel terhadap format berkas yang ada saat ini. Draw.Io mempunyai kemampuan fleksibilitas, dimana pengguna tidak harus menginstal aplikasinya. Apabila pengguna berada di tempat yang berbeda dengan menggunakan komputer yang berbeda juga, hal tersebut tidak menyulitkan

\section{DAFTAR PUSTAKA}

[1] S. Hanum, "Pemanfaatan Aplikasi

Penggambar Diagram Alir

(Flowchart) sebagai Bahan Ajar untuk Mata Kuliah Sistem

Akuntansi di Fakultas Ekonomi pada Perguruan Tinggi Swasta di Kota Medan," Kitabah, vol.

Volume. 1, 2017.

[2] T. Anderson, "Microsoft Visio 2000.," Pers. Comput. World, 2000.

[3] Haviluddin, "Pemanfaatan Open

Source Software (OSS)

Dilingkungan Universitas pengguna. Saat ini internet merupakan suatu kebutuhan maka aplikasi Draw.io dapat digunakan dimana saja selama adanya akses internet. DIA merupakan aplikasi opensource multiplatform dimana semua sistem operasi mendukungnya. Akses internet tidak dibutuhkan selama pengguna telah melakukan instalasi aplikasi tersebut. Pada dasarnya dari aplikasi yang telah disebutkan tersebut tidak ada yang berbeda antara satu dan lainnya.

\section{KESIMPULAN}

Berdasarkan hasil pembahasan tersebut dapat disimpulkan bahwa metode pembelajaran dengan memanfaatkan aplikasi dalam perancangan sistem maka terdapat kesimpulan yang didapat yaitu sebagai berikut :

1. Mahasiswa mendapatkan kemudahan dalam perancangan sistem yaitu perancangan prosedur.

2. Mahasiswa dengan mudah menggunakan fitur-fiitur aplikasinya secara praktif

3. Mahasiswa memahami prosedur dan mampu menganalisis setiap perancangan dari flowchart tersebut.

Mulawarman," J. Inform.

Mulawarman, vol. Vol. 5 No., 2010.

[4] Draw.IO, “About Draw.IO,” 2018. [Online]. Available: http://about.draw.io.

[5] A. K. D. Satori, Metode Penelitian Kualitatif. Bandung: Alfabeta, 2011.

[6] Sugiyono, Metode Penelitian Kualitatif Kuantitatif dan $R \& D$. Bandung: Alfabeta, 2006. 